\title{
Assessing Growers' Perceptions of Effective Extension Methods and Information Communication Technologies for Training Vegetable Growers in Jordan
}

\author{
Ahmad Al-Rimawi ${ }^{1}$, Mohammad Tabieh ${ }^{1} \&$ Hussein Al-Qudah ${ }^{1}$ \\ ${ }^{1}$ Department of Agricultural Economics and Agribusiness Management, Faculty of Agriculture, The University \\ of Jordan, Amman, Jordan \\ Correspondence: Mohammad Tabieh, Department of Agricultural Economics and Agribusiness Management, \\ Faculty of Agriculture, The University of Jordan, Amman 11942, Jordan. Tel: 962-535-5000. E-mail: \\ m.tabieh@ju.edu.jo
}

Received: May 4, 2016

Accepted: May 20, 2016

Online Published: July 25, 2016

doi:10.5539/ijef.v8n8p229

URL: http://dx.doi.org/10.5539/ijef.v8n8p229

\begin{abstract}
The study examined the effectiveness of agricultural extension education methods as perceived by vegetable growers in Jordan to meet their assessed needs in areas of production, marketing and management. A random sample of 98 vegetable growers in two governorates in Jordan was used. Four point Likert-type scales were used as instruments to gather primary data. Cronbach's alpha coefficients ranged from 0.88 to 0.91 indicated high internal consistency for the scales. Nonparametric methods were used to analyze the data based on approximations to normal distribution. The results showed that aged people with basic education and who are very largely dependent on farm income are still the ones most engaged in vegetable farming. The most preferred extension methods by farmers were farm visit, meeting groups of farmers, result demonstrations and farm tours. Low rated methods include information and communications technologies (ICTs). The method to be chosen depends on the goal and adoption stage, i.e. whether we wish to change knowledge, attitude, skills or behavior. Extension staff needs to be trained on how to use ICT tools as an extension method to enable them to train farmers on how they can use them in extension. The involvement of public extension staff in the survey contributes to the selection of extension delivery method on the bases of its ability to deliver the appropriate information to the targeted farmers in the right time.
\end{abstract}

Keywords: assessment, effectiveness, extension methods, ICTs, sustainable development, Jordan

\section{Introduction}

The extension organization provides a linkage between researchers and producers to orient their research work towards farmer's problems and to keep them well informed about the results and problems created from adopting new technologies. The National Extension Strategy stated that policy making should aim to supporting properly targeted farm operators with well founded, technically sound and financially feasible technologies for the varied agro-climatic zones and socio-economic groups of farm holders (MOA, 1998). The selection of extension education method, or extension delivery method, in a particular situation is based on its ability to give the right kind of information to the right people in the right time (Campbell \& Barker, 1997).

The first process in the extension programs planning cycle is concerned with identifying producers' needs, selecting appropriate content and methods in program delivery, managing program delivery, and evaluating program processes and outcomes (Van Den Ban, 1996; Penrose, 1999; Ekanem et al., 2001). Thus, extension staff learns about farmers' problems through needs assessment, and then they are responsible for planning and implementing relevant extension programs and activities which respond to these needs and to farming activities. Identifying needs of farm managers for knowledge and determining the best way to meet those educational needs is a challenge (Young, 1998). Ajzen's Theory of Planned Behavior (TPB) indicated that human behaviors have a common structure and can therefore be predicted. Explaining human behaviors require examining determinant of intentions; their attitude towards the specific behavior, their subjective norms and their perceived behavioral control. Attitudes refer to the individual/ farmer positive or negative evaluation of performing a behavior such as adopting a new technology. This is determined by beliefs relating to the behavior, i.e. adopting a technology 
(behavioral beliefs). Subjective norms refer to the perceptions of whether adopting the technology is socially acceptable and encouraged by the community. The perceived behavioral control is related to the farmers' perception of how difficult the technology will be to carry out, i.e. self efficacy (such as the farmers' judgments of their own capabilities to adopt the technology) and controllability i.e. farmers' perceptions of whether implementing the technology is up to them because of the availability of resources and past experience (Ajzen, 2006).

It is important to measure the knowledge, attitude and practice (KAP) in order to understand what people know about certain things, how they feel and also how they behave (Adhikarya, 1994; Pasiani et al., 2012). The implications of the different KAP levels of the target audience for message development, media selection, and materials development could significantly increase the cost-effectiveness of extension activities (Adhikarya, 1997). Farmers can be made knowledgeable about new technologies through creating awareness, interest and more positive attitudes can be developed towards new methods and materials through mass media channels (i.e. radio, television, printed materials (Ban \& Hawkins, 1988) and ICT (Vignare, 2013). Therefore, varied extension methods can be used to transfer technologies with varying strengths and weaknesses. The method chosen will depend on the goal and adoption stage; whether we wish to change knowledge, attitude or skills, resources and the size and the educational level of the target group. Mass media are the preferred methods for creating awareness as they can reach and inform many people at the same time. Individual and group extension such as farm visits, meetings, field days and demonstrations are important for technical and management skills building and training (Gaya, 1994; Campbell \& Barker, 1997). In practice, multimedia approaches that use different communication channels and utilize several senses, in a coordinated and mutually reinforcing way would give the best results (Nooriafshar, 2004).

Assessing new technologies mentally such as relative economic advantages, social acceptability and practicality (how to use or apply and maintain it) and physical evaluation by trying the new technology on small scale can create more positive attitudes and can develop the skills required in the adoption process(Rogers, 1995). Extension activities help to accelerate the adoption process if new technologies have demonstrated proven successes relative to current ones, it has observed effects, if it is social compatible, simple to learn, and trialable or testable. The wider use of new technology may be stimulated by the promotional work of the private sector, which will stimulate effective demand for extension work on the use of the new technology on individual farms (Ban \& Hawkins, 1988). An important development in extension methods is the advances in information technology that can be used to complement the personal methods. Communication technology (ICT) gives farmers greater control over their access and exposure to information. It enables them to take initiative as information seekers, rather than adopting a passive role as information recipients (Meera, Jhamtani, \& Rao, 2004). Mass media and ICT are good for creating awareness whereby many farmers can be reached within a short time (Vignare, 2013).

The percentage of individuals using the Internet in Jordan increased from 29\% in 2009 to $73 \%$ in 2013 and the percentage of mobile phone subscriptions increased from $101 \%$ in 2009 to $142 \%$ in 2013 (TRC, 2014). This is higher than the percentage of internet users in the Middle East which was $36 \%$ and in the World which was $33 \%$ in 2011 (Vignare, 2013). Text messaging is the most widely used mobile data service worldwide. At present, text messaging is the primary means of contact between the Extension Department and farmers in Jordan (Personal communication with the National Center of Agricultural Research and Extension (NCARE) General Director and his Extension Deputy). The extension agents need to have a better understanding of the best methods for delivering information. This study aims to identify the extension methods and ICT- related methods, preferred by the farmers and how these may relate to the socio-economic characteristics of the growers.

\section{Methodology}

The population for this study was comprised of the vegetable farmers in the irrigated areas of the Jordanian highlands in Mafraq and Balqa Governorates. A random sample of farmers was drawn with the help of the Department of Extension of the NCARE. The sample consisted of 50 growers in each of the two governorates. Forty seven growers in Mafraq and 51 growers in Balqa were eventually interviewed, and thus 98 surveys were analyzed for the study during March-October 2013. A semi-structured questionnaire was used as a tool for data collection. It included both closed- and open-ended questions. Four-points Likert-type items were used for rating perceptions with no middle option to avoid the central tendency bias, i.e. the tendency of respondents to avoid taking a stand by not choosing low or high ratings. The ratings were based on a scale from 1-4, with 1 representing "strongly disagree" and 4 "strongly agree". A 13-items questionnaire was used to rate the attitudes of growers towards the most effective methods to transfer information and technologies. Open-ended questions were used to provide information about their agricultural activities and suggestions about training needs and preferred extension methods. Personal interview were used for conducting the survey. The questionnaire was developed and validated 
by a panel of experts from the NCARE to have sufficient content and face validity. The instrument was then field-tested to ensure usability and reliability. Internal consistency reliability was demonstrated with satisfactory alpha coefficients ranged between 0.88 and 0.91 . Tavakol \& Dennick (2011) reported that a reliability coefficient of 0.70 or higher is acceptable in most social science research situations. Descriptive statistics were employed to profile vegetable growers, and parametric and non-parametric analytical statistics were employed to analyze the data using the SPSS software.

\section{Results and Discussion}

\subsection{Socio-Economic Characteristics of Vegetable Growers}

The socio-economic factors are important in understanding and shaping attitudes, behavior and decisions of individuals (Ajzen, 2006). Table 1 shows that the overall mean age of vegetable growers was 53.6 years and the mean age in Mafraq is higher than Balqa, and the difference between means is statistically significant $(\mathrm{t}-\mathrm{test} \mathrm{p}$ $=0.011)$. These results were consistent with the mean age in irrigated areas ( $\bar{x}=52$ Yrs $)$ according to the Agricultural Census (AC) 2007 (DOS, 2009; AL-Rimawi, 2009). The mean age is also globally in line with case of the EU-27 countries where the mean age in 2010 was 53 Years (European Commission, 2013). The study findings showed that the overall mean number of years of education of vegetable growers was 8.3 years and the number of years of education in Mafraq is higher than Balqa, and the difference between means is statistically significant ( $\mathrm{t}$-test: $\mathrm{p}=0.054)$. Farmers with postsecondary education were $16 \%$ in the AC 1997 and $22 \%$ in the AC 2007 in the study area (Al-Rimawi, 2009), against 8\% for growers in this study. Less than $4 \%$ were found to have educational backgrounds in agriculture against $7 \%$ of EU farm managers (European Commission, 2013) which suggests that most growers learned their profession through practical experience (Al-Rimawi et al., 2016). The study findings showed that the overall mean number of years of experience in agriculture of vegetable growers was 18.9 years and the number of years of experience was significantly higher in Mafraq than Balqa, $(\mathrm{t}$ -test: $\mathrm{p}=0.001$ ). Most of the growers $(84 \%)$ had off farm work, but all growers in Mafraq and $82 \%$ in Balqa had more than $50 \%$ of their income from agriculture. Overall, $91 \%$ of the growers have farming as their main job, income wise, against 69\% in the irrigated holdings in Jordan according to the AC 2007 (Al-Rimawi, 2009). Farmers grew vegetables such as tomatoes, potatoes, eggplant, squash, peppers, cucumber and melons. Farm area was significantly higher in Mafraq than Balqa $(\mathrm{P}=0.0001)$. The results showed that a majority of growers were land owners (62\%), but $49 \%$ of growers in Mafraq against $74 \%$ in Balqa, $\left(\chi^{2}\right.$ test: $\left.p=0.033\right)$. Thus, there is statistically significant association between land tenure and governorate.

Table 1. Socio-economic characteristics of farmers in Mafraq and Balqa

\begin{tabular}{llccccc}
\hline \multicolumn{2}{l}{ Characteristic by Governorate } & Mean & P-Value & CI 95\% & SD & CV \\
\hline Age & Balqa & 51.4 & 0.011 & $48.50-4.08$ & 8.84 & 17.23 \\
(years) & Mafraq & 55.9 & & $53.52-58.18$ & 7.94 & 14.21 \\
& Overall & 53.6 & & $51.84-55.36$ & 8.66 & 16.15 \\
Education & Balqa & 8.88 & 0.054 & $8.31-10.16$ & 3.25 & 36.59 \\
(years) & Mafraq & 7.67 & & $6.85-8.50$ & 2.77 & 36.15 \\
& Overall & 8.30 & & $7.68-8.93$ & 3.08 & 37.05 \\
Experience & Balqa & 16.33 & 0.001 & $13.58-18.15$ & 7.75 & 47.44 \\
agriculture (Years) & Mafraq & 21.74 & & $19.44-24.05$ & 7.84 & 36.05 \\
& Overall & 18.93 & & $17.28-20.58$ & 8.21 & 43.39 \\
Holding area & Balqa & 2.56 & 0.000 & $1.86-2.74$. & 1.88 & 67.23 \\
(ha) & Mafraq & 18.71 & & $15.02-22.41$ & 12.58 & 73.421 \\
& Overall & 10.30 & & $7.91-12.70$ & 11.94 & 15.4 \\
\hline
\end{tabular}

\subsection{Educational Needs for Farmers}

Three scales were used as to rate the farmers' needs to be informed and to improve their skills and practices in the areas of production, marketing ( 10 items each) and business management related areas ( 9 items). The mean overall score of the production and marketing scales were 28.57 and 29.97 , which accounts for $71 \%$ and $75 \%$ of the maximum value, and the overall mean score of the management scale ( $\bar{x}=21.89)$ accounts for $61 \%$ of the maximum value (Al-Rimawi et al., 2016). Levels of the need for training were established using cut off rates for the need for training. Chi-square tests were used to investigate associations between the farmer's preference to extension methods and their socioeconomic characteristics. (Tables $4 \& 5$ ). The results in Table 2 showed that 
only $19 \%$ were in the high level of the need for training in management against $63 \%$ for marketing and $44 \%$ for production.

Table 2. Distribution of farmers by the levels of training needs $(n=98)$

\begin{tabular}{|c|c|c|c|}
\hline Levels & Production needs & Marketing needs & Management needs \\
\hline Low $(<60 \%$ of the Max value) & 15.3 & 7.1 & 45.9 \\
\hline Medium $(60-75 \%)$ & 40.8 & 30.6 & 34.7 \\
\hline High ( $>75 \%$ of the Max value) & 43.9 & 62.3 & 19.4 \\
\hline Total /overall & 100.0 & 100.0 & 100.0 \\
\hline
\end{tabular}

The ratings were high in both governorates in the related aspects of production and marketing which imply the need for training, but, they were low in both governorates in management related areas. Rates in Mafraq Governorate were systemically higher, which indicates that needs are location specific, based on a particular set of farm conditions and socio economic conditions. This finding supports previous research in Australia and the USA that many producers in different parts of the world do not perceive the need to participate in training activities to upgrade their management skills, and were reluctant to participate in training activities (Murray-Prior \& Dymond, 2000; Breazeale et al., 2001; Al-Rimawi et al., 2004). The immediate benefits of improved management skills appear not to be clear enough to the growers (Al-Rimawi et al., 2016). Rogers (1995) stated that the observability of an innovation, as perceived by members of a social system, is positively related to its rate of adoption. The operators' farm management skills are significant to the profitability of farming. They need assistance from extension agents to develop management skills and competencies to cope with a changing farming environment and to run their business for profit (Shepherd, 2011; Kahan, 2013). A study by USAID in 2005 concluded that extension agents and subject matter specialists have to be trained in the areas farm production economics and post-harvest technology and market development (USAID, 2005).

\subsection{Attitudes of Growers towards the Most Effective Extension Methods}

Varied extension methods can be used to transfer technologies with varying strengths and weaknesses. Mass media and ICT are good for creating awareness and knowledge, and developing positive whereby many farmers can be reached within a short time. Individual and group extension is more important for gaining skills (Gaya, 1994). Based on the TPB, the perceptions of farmers are affected by many factors (Ajzen, 2006). These include in this study age, land tenure, size of the farm, education and farm location which have implications on how resources are allocated by the farmers. Attitudes of growers towards the most effective methods to transfer information and technologies were investigated to help policy makers to design extension programs to meet specific needs of farmers. The various extension/outreach methods identified by farmers as more effective are ranked and compared in Table 3.

The results showed that the extension methods that were preferred by farmers included farm visit, meeting groups of farmers, result demonstrations and farm tours were the highest ranked $(\geq 3.00)$ ranging from 3.03 to 3.29. Similar results were found by NALEP (2011) in Kenya, Khan and Akram (2012) in Pakistan where farm visits, demonstrations and field days received high ranking positions. The major advantage of the individual method is that it tends to provide direct personal attention to the grower's specific needs (Kingiri \& Nderitu, 2014) and it facilitates a dialogue in which extension worker can learn from the farmers as well as passing on advice, and group methods promote sharing of experiences and knowledge (Buyinza, Nalule, \& Byakagaba, 2009). These were followed by contact farmers, field days, mass media methods including printed extension materials, with medium scores $(\bar{x}=2.4-2.99)$ ranging from 2.59 to 2.92 . Low rated methods $(<2.4)$ include farm schools and information and communications technology (ICT) such as electronic methods of communication (mobiles calls and message texting (SMS)), electronic media (CDs... diskettes...) and internet to provide extension. Anandajayasekeram, Davis, and Workneh (2007) concluded that farm field school is a useful methodology and has produced good results, but not an alternative to existing extension systems. Some of its principles could be picked up and incorporated into agricultural extension, to make it more effective at reaching small and marginalized farmers. 
Table 3. Vegetables growers' perceptions of effective extension methods $(n=98)$

\begin{tabular}{|c|c|c|c|c|c|c|c|}
\hline Use of: & Strongly disagree & Disagree & Agree & Strongly agree & Mean & SD & $\mathrm{CV}$ \\
\hline Farm visit & $4(4.1)$ & $5(5.1)$ & $48(49.0)$ & $41(41.8)$ & 3.29 & 0.746 & 0.227 \\
\hline Meeting groups of farmers & $5(5.1)$ & $8(8.2)$ & $48(49.0)$ & $37(37.8)$ & 3.19 & 0.795 & 0.249 \\
\hline Demonstrations & $5(5.1))$ & $9(9.2)$ & $53(54.1)$ & $31(31.6)$ & 3.12 & 0.777 & 0.249 \\
\hline Farm tours & $3(3.1)$ & $15(15.3)$ & $56(57.1)$ & $24(24.5)$ & 3.03 & 0.724 & 0.239 \\
\hline Contact farmers & $4(4.1)$ & $22(22.4)$ & $50(49.0)$ & $22(22.8)$ & 2.92 & 0.782 & 0.268 \\
\hline Field days & $6(6.1)$ & $20(20.4)$ & $53(54.1)$ & $19(19.4)$ & 2.87 & 0.795 & 0.277 \\
\hline Mass media/ TV Radio & $12(12.2)$ & $20(20.4)$ & $54(55.1)$ & $12(12.2)$ & 2.67 & 0.847 & 0.317 \\
\hline Printed materials & $8(8.2)$ & $31(31.6)$ & $52(53.1)$ & $7(7.1)$ & 2.59 & 0.744 & 0.287 \\
\hline Mobile communication/SMS & $22(22.4)$ & $24(24.5)$ & $45(45.9)$ & $7(7.1)$ & 2.38 & 0.914 & 0.384 \\
\hline Electronic materials (CDs...) & $24(24.5)$ & $33(33.7)$ & $35(35.7)$ & $6(6.1)$ & 2.23 & 0.894 & 0.401 \\
\hline Farm schools & $24(24.5)$ & $39(39.8)$ & $29(29.6)$ & $6(6.1)$ & 2.17 & 0.874 & 0.403 \\
\hline Internet to provide extension & $35(35.7)$ & $38(38.8)$ & $20(20.4)$ & $5(5.1)$ & 1.95 & 0.878 & 0.450 \\
\hline
\end{tabular}

Regarding ICTs, people fear the unknown and have a tendency not to agree with the things they cannot understand. Extension staff needs to be trained on how to use ICT tools as an extension method to enable them to train farmers on how they can use ICT tools in extension.

Establishing an ICT center makes agricultural information available on the Internet. This will increase subject-matter specialist access to information, and would link the field extension staff to the ICT center (Swanson \& Rajalahti, 2010). Training activities are costly and time-consuming, which makes ICT training very appealing. ICT is cheaper, it does not need physical classroom facilities and its scheduling is much more convenient. E-learning makes it possible to have expert instructors who would otherwise be very difficult, if not impossible, to reach (Quesada-pineda et al., 2011).

\subsection{Statistical Analysis of Selected Characteristics and Preference to Extension Methods}

Chi-square tests were run to determine the relationships between the farmers'socio economic characteristics and the production, marketing and management levels on one side, and the preference to extension methods used on the other side. At the 5\% level of significance or lower, the results revealed in Tables 4 and 5 that the extension method used was significantly related to; the governorate for the use of mass media and use of mobile calls and SMSs $(\mathrm{p} \leq 0.05)$, the age groups and education levels for the use of electronic extension materials (CDs, diskettes), use of internet to provide extension and use of mobile calls and SMSs ( $p \leq 0.01)$, area groups to use of mobile calls and SMSs $(p \leq 0.05)$, time spent in agriculture for the use of individual extension, demonstrations, use of electronic extension materials use of internet to provide extension and use of mobile calls and SMSs ( $\mathrm{p} \leq$ $0.05)$, the production scale levels for the use of individual extension, demonstrations $(p \leq 0.01)$ and use of mass media $(\mathrm{p} \leq 0.05)$ and for the marketing and management scales levels for the use of individual extension, demonstrations, mass media, use of electronic extension materials, use of internet to provide extension and use of mobile calls and SMSs $(\mathrm{p} \leq 0.01)$. The extension method used was not significantly related, at the $5 \%$ level of significance or lower to the type of holding, but it was significantly related, at the $10 \%$ level of significance to the use of demonstrations and use of internet to provide extension. Group extension method in general was significantly related to governorate $(\mathrm{p} \leq 0.05)$ and the production, marketing and management scales at $1 \%$ level of significance. Similarly, farm tours and field days were significantly related to the production, marketing and management scales at $1 \%$ level of significance, and printed media at $5 \%$ level of significance.

Table 4. Associations between vegetables growers' characteristics and their preference of extension method $(\mathrm{N}=$ 98)

\begin{tabular}{|c|c|c|c|c|c|c|}
\hline \multirow[t]{2}{*}{ Socio economic characteristics of vegetables growers } & \multicolumn{2}{|c|}{ Individual extension } & \multicolumn{2}{|c|}{ Demonstrations } & \multicolumn{2}{|c|}{ Mass media } \\
\hline & $\chi^{2}$ & P-value & Value & P-value & Value & P-value \\
\hline Governorate (Mafraq, Balqa) df $=3$ & - & NS & 7.26 & 0.064 & 9.32 & 0.025 \\
\hline Age $(<40,40-50,>50 \mathrm{Yr}),. \mathrm{df}=6$ & - & NS & - & NS & - & NS \\
\hline Education level $(\leq 6,7-9,10-12,>12$ Yrs $)$, df $=9$ & - & NS & - & NS & - & NS \\
\hline Holding type (owned, rented, sharecropped) $d f=6$ & - & NS & 11.16 & 0.084 & - & NS \\
\hline Area group $(\leq 2, \quad 2.1-5, \quad 5.1-15, \geq 20 \mathrm{ha}), \mathrm{df}=9$ & - & NS & - & NS & 14.83 & 0.095 \\
\hline Time spent in agriculture $(100,>50,<50 \%)$, df $=6$ & 13.69 & 0.033 & 15.50 & 0.017 & - & NS \\
\hline The production training scale levels, $\mathrm{df}=6$ & 19.53 & 0.003 & 15.18 & 0.0019 & 14.96 & 0.021 \\
\hline The marketing training needs scale levels, $\mathrm{df}=6$ & 27.66 & 0.000 & 39.62 & 0.000 & 24.82 & 0.000 \\
\hline The management training needs scale levels $(\mathrm{df}=6)$ & 34.77 & 0.003 & 24.71 & 0.000 & 26.39 & 0.000 \\
\hline
\end{tabular}


The younger and more educated, those who spent less than 50\% of time in farming and those who were more willing to have training on production, marketing and management related areas in Mafraq, were more receptive to information communication technologies, as well as to group extension/ demonstrations and the use of mass media.

Table 5. Associations between growers' characteristics and their preference of extension method $(N=98)$.

\begin{tabular}{lcccccc}
\hline Socioeconomic characteristics of vegetables growers & \multicolumn{2}{c}{ Electronic materials } & \multicolumn{2}{c}{ Internet extension services } & \multicolumn{2}{c}{ Mobile calls / SMSs } \\
\cline { 2 - 7 } & $\chi 2$ & P-value & $\chi^{2}$ & P-value & $\chi^{2}$ & P-value \\
\hline Governorate (Mafraq, Balqa) $\mathrm{df}=3$ & 6.45 & 0.092 & - & $\mathrm{NS}$ & 9.41 & 0.024 \\
Age $(<40,40-50,>50 \mathrm{Yr}$.), $\mathrm{df}=6$ & 17.73 & 0.007 & 16.78 & 0.010 & 22.04 & 0.001 \\
Education level $(\leq 6,7-9,10-12,>12 \mathrm{Yrs}), \mathrm{df}=9$ & 23.21 & 0.006 & 20.86 & 0.013 & 22.38 & 0.008 \\
Holding type (owned, rented, sharecropped) $\mathrm{df}=6$ & - & $\mathrm{NS}$ & 11.51 & 0.074 & - & $\mathrm{NS}$ \\
Area group ( $\leq 2, \quad 2.1-5, \quad 5.1-15, \geq \quad 20 \mathrm{ha}), \mathrm{df}=9$ & - & $\mathrm{NS}$ & - & $\mathrm{NS}$ & 18.22 & 0.033 \\
Time spent in agriculture $(100,>50,<50 \%), \quad \mathrm{df}=6$ & 13.07 & 0.042 & 16.34 & 0.012 & 12.39 & 0.054 \\
The production training scale levels, $\mathrm{df}=6$ & - & $\mathrm{NS}$ & 10.39 & 0.109 & 10.85 & 0.093 \\
The marketing training needs scale levels, $\mathrm{df}=6$ & 28.44 & 0.000 & 29.62 & 0.000 & 32.90 & 0.000 \\
The management training needs scale levels $(\mathrm{df}=6)$ & 21.85 & 0.001 & 16.94 & 0.010 & 33.95 & 0.000 \\
\hline
\end{tabular}

\section{Conclusions and Implications}

The results showed that aged people with basic education and who are very largely dependent on farm income are still the ones most engaged in vegetable farming. Farmers in Mafraq as compared to farmers in Balqa were found to be older, more experienced in agriculture, less educated, had less percentage of land owners, part time farmers and all of them have more than $50 \%$ of their income from agriculture.

Farm visit, meeting groups of farmers, result demonstrations and farm tours were observed as the most preferred methods. Information and communications technology (ICT) such as electronic methods of communication (mobiles/sms), electronic media (CDs... diskettes...) and internet to provide extension were low rated. Yet, growers in Mafraq, the younger and more educated, part time farmers and those who were more willing to have training on production, marketing and management related areas were more receptive to ICTs.

The percentage of individuals using the Internet in Jordan was 73\% in 2013and the percentage of mobile phone subscriptions was $142 \%$ in in 2013 (TRC, 2014). The implication is that the extension staff needs to be trained on how to use ICT tools as an extension method and to enable them to train the willing farmers on how they can use ICT tools in extension.

The NCARE already has a website, and has the capacity to establish an ICT center and makes agricultural information available on the Internet to promote subject-matter specialist access to information. Linking the field extension staff to the ICT center provide them a broader source of technical and managerial information.

\section{Acknowledgements}

The project was supported by the Deanship of Scientific research of the University of Jordan.

The authors would like to thank the Extension staff of the National Center for Agricultural Research and Extension for their assistance in organizing interviews with growers.

\section{References}

Adhikarya, R. (1994). Strategic extension campaign: A participatory-oriented method of agricultural extension. Rome: FAO/United Nations.

Adhikarya, R. (1997). Implementing strategic extension campaigns. In B. Swanson, R. Bentz, \& A. Sofranko (Eds.), Improving agricultural extension. A reference manual, FAO.

Ajzen, I. (2006). Behavioral interventions based on the theory of planned behavior. Retrieved from http://people.umass.edu/aizen/pdf/tpb.intervention.pdf

Al-Rimawi, A. (2009). Agricultural farm structure in Jordan: holding and holder characteristics. A paper presented to the workshop of analyzing agricultural census results 2007, Department of Statistics, Amman, Jordan, and July, 2009.

Al-Rimawi, A., Al-Hadidi, N., Tabieh, M., \& Al-rusheidat, J. (2016). An Investigation of Training Needs 
Assessment of Vegetable Growers in Jordan. Journal of Agricultultral Sciences, Forthcoming.

Al-Rimawi, A., Karablieh, E., \& Al-Kadi, A. (2004). An investigation into the perceived farm management and marketing educational needs of farm operators. Journal of Agricultural Education, 45(3). http://dx.doi.org/10.5032/jae.2004.03034

Anandajayasekeram, P., Davis, K., \& Workneh, S. (2007). Farmer Field Schools: An Alternative to Existing Extension Systems? Experience from Eastern and Southern Africa. Journal of International Agricultural and Extension Education, 14(1). http://dx.doi.org/10.5191/jiaee.2007.14107

Ban, A. W., \& Hawkins, H. S. (1988). Agricultural Extension. England: Longman Scientific \& Technical.

Breazeale, D., Myer, G., \& Hill, G. (2001). What do you know about your clients? Implications for extension financial management training. JOE, 39(6). Retrieved from http://www.joe.org/joe/2001december/rb5.html

Buyinza, M., Nalule, R., \& Byakagaba, P. (2009). Land Tenure Systems and Extension Methods: Assessment of Agroforestry Adoption in Kalungu Sub-County, Masaka District, Uganda. Environmental Research Journal, 3(2), 42-45. http://dx.doi.org/10.4314/jext.v7i1.2779

Campbell, D., \& Barker, St. C. (1997). Selecting appropriate content and methods in program delivery. In B. Swanson, R. Bentz, \& A. Sofranko (Eds.), Improving agricultural extension: A reference manual. FAO, Rome.

DOS. (2009). General results of the Agricultural Census of (2007). Department of Statistics, Amman, Jordan.

Ekanem, E., Singh, S., Muhammad, S., Tegegne, F., \& Akuley-Amenyenu, A. (2001). Differences in district extension leaders' perceptions of the problems and needs of Tennessee small farmers. JOE, 39(4). Retrieved from http://www.joe.org/joe/2001august/rb4.php

European Commission. (2013). Rural development in the EU statistical and economic information report 2013. European Commission Directorate-General for Agriculture and Rural Development. Retrieved from http://ec.europa.eu/agriculture/statistics/rural-development/2013/full-text_en.pdf

Gaya, A. (1994). Extension education in agricultural and rural development: Role of international organizations the FAO experience. In P. Plaza (Ed.), La vulgarisation, composante du développementagric ole et rural: Actes du séminaire de Grenade Montpellier (CIHEAM Cahiers Options Méditerranéennes, 2(4), 33-45).

Kahan, D. (2013). Market-oriented farming: An overview. Farm management extension guide (1). FAO, Rome.

Khan, A., \& Akram, M. (2012). Farmers perception of extension methods used by extension personnel for dissemination of new agricultural technologies in Khyber Pakhtunkhwa Pakistan. Sarhad Journal of Agriculture, 28(3). Retrieved from http://www.aup.edu.pk/sj_pdf/21-14-65-2012_\%281\%29\%5B1\%5D.pdf

Kingiri, A., \& Nderitu, S. (2014). Assessment of extension and advisory methods and approaches to reach rural women (examples from Kenya). USAID, Modernizing Extension and Advisory Services (MEAS), USA.

Meera, S., Jhamtani, A., \& Rao, D. (2004). Information and Communication Technology in Agricultural Development: A Comparative Analysis of Three Projects from India. Agricultural Research and Extension Network Paper No. 135. Washington DC: World Bank.

MOA. (1998). National Strategy for Agricultural Extension. Ministry of Agriculture, Jordan.

Murray-Prior, R., Hart, D., \& Dymond, J. (2000). An Analysis of Farmer Uptake of Formal Farm Management Training in Australia. Australian Journal of Experimental Agriculture, 40(4). http://dx.doi.org/10.1071/EA99111

NALEP. (2011). A Guide to Effective Extension Methods for Different Situations. National Agriculture and Livestock Extension Program (NALEP).

Nooriafshar, M. (2004). A multi-sense approach to information reception and knowledge creation in learning. In 3rd Pan-Commonwealth Forum on Open Learning, July 2004, Dunedin, New Zealand.

Pasiani, J., Torres, P., Roniery, S., Diniz, B., \& Caldas, E. (2012). Knowledge, attitudes, practices and biomonitoring of farmers and residents exposed to pesticides in Brazil. International Journal of Environmental Research and Public Health, 9(9).

Penrose, D., Smith, P., \& Vollborn, E. (1999). Production, processing, and marketing opportunities for Athens county, Ohio farmers: assessing needs and creating solutions. JOE, 37(6).

Quesada-Pineda, H. J., Conn, S. S., \& Scarlett, L. (2011). A survey of educational needs and online training 
perceptions in the wood products industry. JOE, 49(1). Retrieved from http://www.joe.org/joe/2011february/rb6.php

Rojers, E. (1995). Diffusion of Innovations (4th ed). New York, USA: The Free Press.

Schwarz, M. H., \& Gibson, J. (2010). A needs assessment of aquaculture extension agents, specialists, and program administrators in extension programming. JOE, 48(2). Retrieved from http://www.joe.org/joe/2010april/a6.php

Shepherd, A. (2011). Understanding and using Market Information. Marketing Extension Guide 2, FAO 2011.

Swanson, B., \& Rajalahti, R. (2010). Strengthening agricultural extension and advisory systems: Procedures for assessing, transforming, and evaluating extension systems. Agriculture and rural development discussion paper 45, the World Bank.

Tavakol, M., \& Dennick, R. (2011). Making sense of Cronbach's alpha. International Journal of Medical Education, 2, 53-55. http://dx.doi.org/10.5116/ijme.4dfb.8dfd

TRC. (2014). Annual Report (2013). Telecommunication Regulatory Commission, Jordan.

USAID. (2005). Assessment of Agricultural Extension Services in Jordan Valley and Amman-Zarqa Basin Highlands in Jordan. United States Agency for International Development (USAID), February 2005.

Van Den Ban, A. W., \& Hawkins, H. S. (1996). Agricultural extension (2nd ed.). Wiley-Blackwell.

Vignare, K. (2013). Options and strategies for information and communication technologies within agricultural extension and advisory services. MEAS Discussion Paper, USAID.

Young, R. C. (1998). Determining Needs of Farmers for Management Knowledge. JOE, 36(3). Retrieved from http://www.joe.org/joe/1998june/iw1.html

\section{Copyrights}

Copyright for this article is retained by the author(s), with first publication rights granted to the journal.

This is an open-access article distributed under the terms and conditions of the Creative Commons Attribution license (http://creativecommons.org/licenses/by/3.0/). 